\title{
Short Communication: Infrared Thermography and Visual Examination of Hooves of Dairy Cows in Two Stages of Lactation
}

\author{
A. Nikkhah, ${ }^{1}$ J. C. Plaizier, ${ }^{1}$ M. S. Einarson, ${ }^{1}$ R. J. Berry, ${ }^{2}$ S. L. Scott, ${ }^{3}$ and A. D. Kennedy ${ }^{1}$ \\ ${ }^{1}$ Department of Animal Science, University of Manitoba, Winnipeg, MB, R3T 2N2 Canada \\ ${ }^{2}$ Manitoba Agriculture, Food and Rural Initiatives, Winnipeg, MB, R3T 5S6 Canada \\ ${ }^{3}$ Agriculture and Agri-Food Canada, Brandon, MB, R7A 5 Y3 Canada
}

\section{ABSTRACT}

Hooves of 16 lactating Holstein cows were examined twice for sole hemorrhages and underrun heels. Images of hooves were taken using infrared thermography to determine the temperatures of the coronary band and that of a control area above the coronary band. To adjust for skin (control) temperature, the difference $(\Delta \mathrm{T})$ between the coronary band and the control area was calculated. Effects of stage of lactation, that is, $\leq 200 \mathrm{~d}$ in milk (DIM) vs. $>200$ DIM, on temperature of the coronary band, $\Delta \mathrm{T}$, and visual abnormalities were determined. Temperatures of the coronary bands of cows were greater for cows $\leq 200$ DIM $(n=17)$ than for cows $(\mathrm{n}=15)$ in late lactation $\left(25.5 \pm 1.3\right.$ vs. $\left.21.0^{\circ} \mathrm{C}\right)$. The $\Delta \mathrm{T}$ was also greater for cows $\leq 200 \mathrm{DIM}$ compared with those $>200 \mathrm{DIM}\left(6.1 \pm 0.8\right.$ vs. $\left.3.3 \pm 0.9^{\circ} \mathrm{C}\right)$. The $\Delta \mathrm{T}$ was greater for lateral claws than for medial claws (5.2 \pm 0.6 vs. $\left.4.2 \pm 0.6^{\circ} \mathrm{C}\right)$. Chi-square analysis revealed that the frequency of sole hemorrhages in hind lateral claws was significantly higher for cows $\leq 200$ DIM compared with those in late lactation. In contrast, underrun heel was more frequently observed among cows $>200$ DIM. Increased temperatures of the coronary band and $\Delta \mathrm{T}$ in early/midlactation coincided with increased incidence of sole hemorrhages, but not to incidences of underrun heels. Because higher hoof temperatures occurred in cows $\leq 200$ DIM compared with cows later in lactation, measurement of hoof temperatures among cows in early lactation may be useful in monitoring hoof health.

(Key words: infrared thermography, laminitis, lactation stage, dairy cow)

Abbreviation key: CBT = coronary band temperature, IRT = infrared thermography, SH = sole hemorrhages, $\Delta \mathbf{T}=$ difference between coronary band temperature (CBT) and the skin temperature above the coronary band, $\mathbf{U R}=$ underrun heels.

Received January 19, 2005.

Accepted April 29, 2005.

Corresponding author: J. C. Plaizier; e-mail: plaizier@ms. umanitoba.ca.

\section{INTRODUCTION}

Lameness results in major economic losses on dairy farms (Green et al., 2002). Hoof abnormalities such as laminitis are major contributors to lameness (Nocek, 1997). Laminitis, or the inflammation of the laminae within the claw, has been associated with a fluctuating and low ruminal $\mathrm{pH}$, leading to bacterial lysis and release of vasoactive substances into the systemic circulation (Nocek, 1997). The release of vasoactive substances into the blood stream can lead to the development of vascular shunts in the lamellar tissues of the hoof (arteriovenous anastomoses), sole hemorrhages (SH), and corium tissue breakdown in the hoof(Nocek, 1997). This cascade can predispose more susceptible parts of the hoof such as the heel and weight-bearing surfaces of the sole to environmental/microbial damages, resulting in heel erosion and underrun heel (UR) (Nocek, 1997; Berry, 1999).

Infrared thermography (IRT) is a noninvasive technique capable of detecting thermal radiation from the surface of any object (Eddy et al., 2001). In animals, the body surface temperature is a function of blood flow and metabolism rate of the underlying tissues. Thus, the physiological state of the underlying cells could potentially be assessed by measuring skin temperature using IRT (Eddy et al., 2001). Infrared thermography has been used to diagnose inflammatory conditions such as sole abscesses and laminitis in horses (Eddy et al., 2001), to predict changes in udder temperature in dairy cows (Berry et al., 2003), and to detect inflammation associated with hot-iron and freeze branding in cattle (Schwartzkopf-Genswein and Stookey, 1997), and bovine viral diarrhea infection in calves (Schaefer et al., 2004). Soles of hooves affected by subclinical laminitis commonly appear soft and warm long before the appearance of yellowish discoloration, lesions, and ulcers (Nocek, 1997). Hence, IRT may prove useful for early detection of laminitis, allowing interventions that could prevent or attenuate subsequent lameness.

The objective of this study was to evaluate the capability of IRT to detect effects of 2 stages of lactation and parity on hoof temperature in dairy cows and rela- 
tionship to visual abnormalities of the hoof (sole hemorrhages and underrun heels) that are indicative of laminitis.

A total of 16 lactating Holstein cows were examined twice; either in early/midlactation $(\leq 200 \mathrm{DIM})$ or in late lactation ( $>200$ DIM). Cows were housed in a tie-stall barn at the Glenlea Research Station, University of Manitoba. Milk production averaged $35.9 \pm 7.4 \mathrm{~kg} / \mathrm{d}$ for cows $\leq 200$ DIM and $26.9 \pm 6.5 \mathrm{~kg} / \mathrm{d}$ for cows $>200$ DIM, respectively $(P<0.01)$. At the first sampling day, the experiment included 3 first-, 8 second-, 3 third-, and 2 fourth-parity cows. Cows $\leq 200$ DIM received a TMR containing (DM basis) $14.8 \%$ alfalfa silage, $20.7 \%$ corn silage, $6.0 \%$ alfalfa hay, $42.0 \%$ rolled barley grain-based energy supplement, $11.4 \%$ corn distillers grain-based protein supplement, and $5.1 \%$ sunflower seeds. Cows $>200$ DIM received a TMR with (DM basis) $33.3 \%$ alfalfa silage, $16.3 \%$ corn silage, $3.9 \%$ alfalfa hay, $34.6 \%$ rolled barley grain-based energy supplement, and $11.9 \%$ corn distillers grain-based protein supplement. The respective dietary levels of $\mathrm{CP}, \mathrm{NDF}$, forage NDF, and NFC (on a DM basis) were 18.1, 34.1, 22.6, and $38.5 \%$ for cows $\leq 200$ DIM, and $18,36.7,28.1$, and $36.6 \%$ for cows $>200$ DIM. Respective fresh TMR were provided once daily at the same time $(0900 \mathrm{~h})$ for all experimental cows to minimize the effects of feed-derived heat production and circadian rhythmicity of the body temperature on IRT measurements. Cows were managed in accordance with Canadian Council of Animal Care guidelines (CCAC, 1993). Except for sampling days, cows were routinely allowed to exercise for $2 \mathrm{~h} / \mathrm{d}$ in an outdoor area.

Visual examinations and IRT measurements of hooves were conducted at 2 to $5 \mathrm{~h}$ postfeeding on November 10, 2001 (12 cows $\leq 200 \mathrm{DIM}$ and 4 cows $>200$ DIM), and February 15, 2002 (5 cows $\leq 200$ DIM and 11 cows $>200$ DIM). The DIM for cows $\leq 200$ DIM ranged from 17 to $200 \mathrm{~d}$ (mean $\pm \mathrm{SE}=128 \pm 14.1 \mathrm{~d}$ ), whereas the DIM for cows $>200$ DIM ranged from 226 to $376 \mathrm{~d}$ (mean $\pm \mathrm{SE}=282 \pm 12.5 \mathrm{~d}$ ). On sampling dates, cows had been receiving respective rations for at least $3 \mathrm{wk}$. Ambient temperatures were 6.7 and $5.7^{\circ} \mathrm{C}$ on the first and second sampling days, respectively, and all samplings were conducted in an indoor environment away from drafts.

Before conducting IRT and scoring visual abnormalities, the hooves of all cows were trimmed professionally with a hoof grinder. Cows were restrained in a freestanding hoof-trimming stall, and hooves were projected upwards and free from the floor before and during the examination. A hoof knife was used to pare away a minimal amount of hoof horn $(1 \mathrm{~mm})$ to expose the sole surface. All 8 claws of each cow (i.e., medial and lateral claws of 2 front and 2 hind hooves) were scored for SH and UR. For SH, a combination of the scoring systems from Greenough and Vermunt (1990) and Bergsten (1993) was used as follows: $0=$ no hemorrhages or discoloration; 1 = slight hemorrhages or faint discoloration in a small area; 2 = faint discoloration or blush in a large area, or trace light-red or brown discoloration in a small area; 3 = brown discoloration in a large area, or clear red discoloration in a small area; $4=$ obvious, clear red discoloration in a large area; $5=$ loss of continuity of horn, corium open to the environment and presence of fresh or clotted blood; and $6=$ clinical lesion and sole ulcers. Underrun heels were defined as cracks of different depth in the heel and sole surfaces and the junction of soft heel and sole area. Such cracks and resultant fissures, whether caused by $\mathrm{SH}$ in earlier stages of lactation or because of inferior housing and bedding, provide suitable conditions for microbial growth (Nocek, 1997). Double soles were also included in this definition. Underrun heels were then scored based on the depth of the fissures in each claw, i.e., $1=$ shallow fissures, $1 \mathrm{~mm} ; 2=$ moderate fissures, 2 to 3 $\mathrm{mm} ; 3$ = deep fissures, $>3 \mathrm{~mm}$, as described by Berry (1999).

The infrared images were taken from the dorsal view of all hooves to monitor the temperature of coronary band. The coronary band, or the distinct transition line between skin and hoof, anatomically overlies the tissues that are rich in vessels and nerves, and which distribute the nutrients throughout the hoof (Greenough et al., 1981). Infrared thermography images were captured at 2 to $5 \mathrm{~h}$ postfeeding. For imaging purposes, the coronary band was preferred to sole area because the cold, keratinized horn layer covering the sole area (and acting as an insulator) would not truly represent the corium blood flow and hoof temperature. All images were scanned using a hand-held portable infrared camera (FLIR Inframetric 760, Boston, MA), which was calibrated to ambient temperature and absorptive conditions on each sampling day. The emissivity value settled on the camera before conducting scanning was 0.93 . To reduce the effects of environmental factors on thermal data, all images were scanned within the barn and at the same distance ( 1.5 to $2 \mathrm{~m}$ ) from the subject. The dorsal surface of hoof was freed of any debris and moisture before images were taken. Cows were moved to a freestanding hoof-trimming stall and, after visual examination of hooves (10 to $20 \mathrm{~min}$ ), the IRT images were taken. Images were captured using a fixed $20^{\circ} \mathrm{C}$ range, and care was taken to ensure that the range of temperature over the hoof surface was within that range. The continuous output for each animal in each collection time was saved for 5 to $10 \mathrm{~s}$ onto digital video (Sony DCR-TRV520, Sony Corp., Tokyo, Japan), with 30 individual frames/s recording. A single 


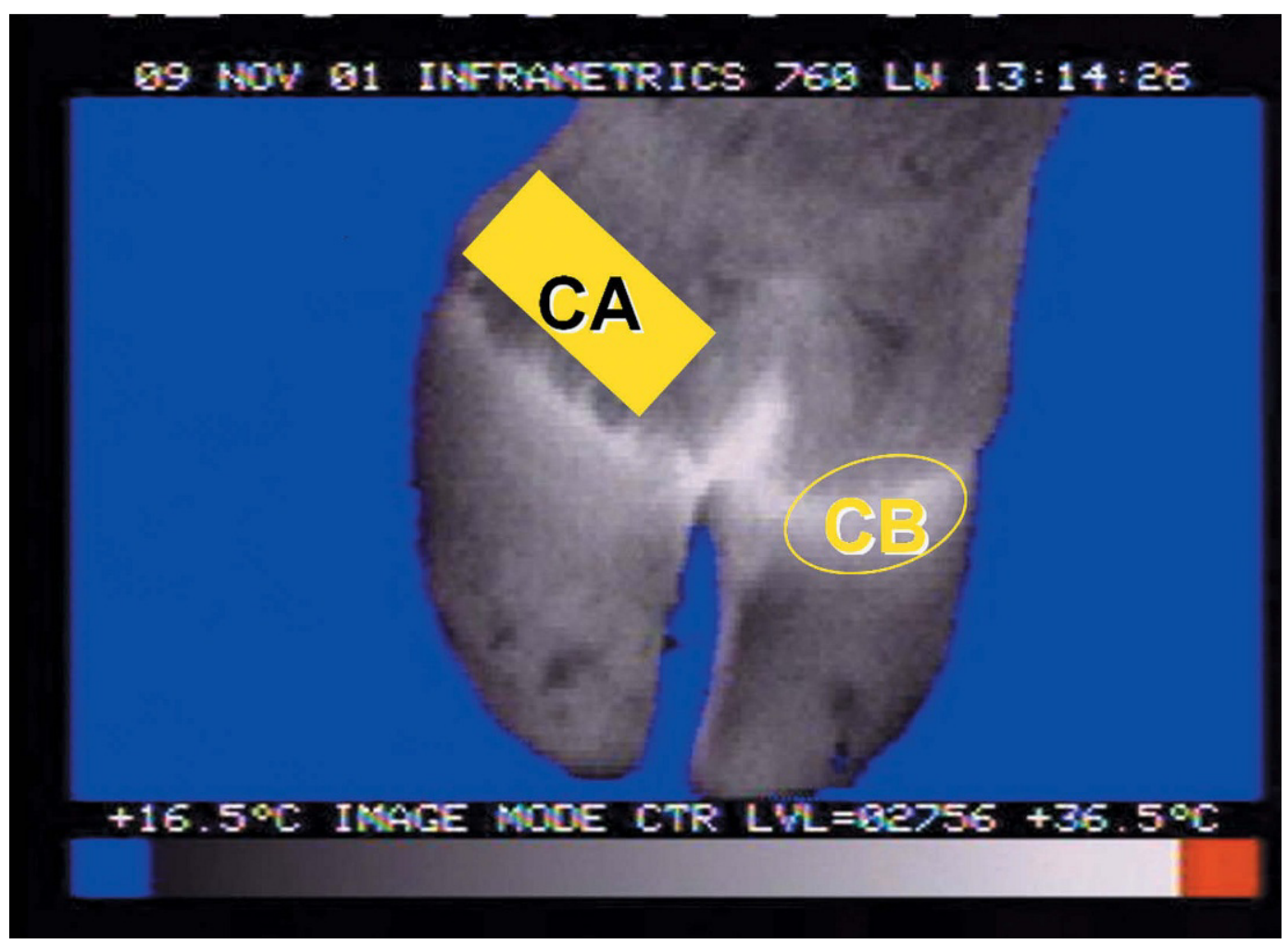

Figure 1. A thermographic image of dorsal front hoof with different colors representing variations in heat. The white-colored area of the coronary bands (CB) was warmer. For each claw, $\Delta \mathrm{T}$ was calculated by deducting maximum temperature of a control area $(\mathrm{CA}$; yellow rectangle) from that of CB (oval area). Red and blue colors at the ends of the scale represent the warmest and coolest regions, respectively.

digitized image was captured as a still and saved as a gray-scale graphics file before analysis using Image $\mathrm{J}$ software (v. 1.30, National Institutes of Health, Research Services Branch, Bethesda, MD). The coronary sample for temperature measurement was defined by tracing the coronary band for each claw (oval, Figure 1 ), excluding the cleft area between 2 claws. Images were calibrated by relating each of the shades of gray on the digitized image to a specific temperature for all pixels. These values then were mapped to degrees centigrade, and the maximum temperature of the coronary band (CBT) was determined. To remove the effect of outlier maximum temperatures related to extraneous particles or too few $(<5)$ pixels exhibiting the maximum temperature, the relative maximum temperature was calculated. A control area of skin (rectangle, Figure 1) above the coronary band was also traced, and its maximum temperature was deducted from the CBT to obtain a less variable value which was defined as $\Delta \mathbf{T}$.

The Proc MIXED procedure of SAS (SAS, 1999; SAS Inst., Inc., Cary, NC) was used to assess the fixed effect of stage of lactation on both CBT and $\Delta \mathrm{T}$. The statistical model used was a split-split plot, with cow as the main plot, hoof location within each cow (front vs. hind) as the subplot, and claw location within each hoof (lateral vs. medial) as the sub-subplot. The effects of cow, cow $\times$ stage of lactation, and cow $\times$ hoof location $\times$ stage of lactation were considered random. To test the effect of parity and its interaction with stage of lactation in the model, cows were divided into 2 parity groups, with parity group 1 including cows in parities 1 and 2 and parity group 2 including cows in parities 3 and 4 . Incidences of SH and UR in cows $\leq 200$ DIM and $>200$ DIM in conjunction with the changes in hoof temperature, were evaluated using $\chi^{2}$ frequency analysis as a nonparametric statistical procedure. This was to calculate the frequency of abnormality scores exceeding the threshold for disturbed claw health (score of 2 for both SH and UR).

Both CBT and $\Delta \mathrm{T}$ were higher $(P<0.05)$ in cows $\leq 200$ DIM than in cows $>200$ DIM (Table 1 ), indicating a higher temperature of the laminae compared with cows in late lactation. This coincided with a more frequent $(P<0.05)$ incidence of SH in lateral claws at $\leq 200$ DIM compared with >200 DIM (Table 2). Infrared thermography was used to measure the CBT because the coronary band overlies tissues that distribute blood and nutrients throughout the dermis layer (corium). 
Table 1. Effects of stage of lactation (SL), parity group (PG), and claw location (CL) on temperatures of the coronary band (CBT) and the difference $(\Delta \mathrm{T})$ between CBT and temperatures of control areas above the coronary band $( \pm \mathrm{SEM})$.

\begin{tabular}{|c|c|c|c|c|c|c|c|c|c|c|}
\hline \multirow[b]{2}{*}{ Item } & \multicolumn{2}{|c|}{ Stage of lactation } & \multicolumn{2}{|c|}{ Parity group ${ }^{1}$} & \multicolumn{2}{|c|}{ Claw location } & \multicolumn{4}{|c|}{ Effects, $P=$} \\
\hline & $\leq 200 \mathrm{DIM}$ & $>200$ DIM & 1 & 2 & Lateral & Medial & SL & $P G$ & CL & $\mathrm{SL} \times \mathrm{PG}$ \\
\hline $\mathrm{CBT},{ }^{\circ} \mathrm{C}$ & $25.4 \pm 1.3$ & $21.0 \pm 1.5$ & $24.0 \pm 1.2$ & $22.4 \pm 1.6$ & $23.1 \pm 1$ & $23.2 \pm 2$ & 0.03 & 0.42 & 0.88 & 0.09 \\
\hline$\Delta \mathrm{T},{ }^{\circ} \mathrm{C}$ & $6.1 \pm 0.8$ & $3.3 \pm 0.9$ & $5.9 \pm 0.7$ & $3.5 \pm 0.9$ & $5.2 \pm 0.6$ & $4.2 \pm 0.6$ & 0.04 & 0.05 & 0.03 & 0.12 \\
\hline
\end{tabular}

${ }^{1}$ Parity group 1 = first and second parities; group 2 = third and fourth parities.

Increased temperature due to inflammation of the laminae should, therefore, result in increased CBT. Higher hoof temperature and a high incidence of SH were expected in cows earlier in lactation, as these cows had higher milk production and consumed a higher concentrate diet than cows >200 DIM. Hence, it is expected that nutrient metabolism was greater, rumen $\mathrm{pH}$ was lower, and the probability of inflammation of the hoof and laminitis was higher in early/midlactation cows compared with those in late lactation (Nocek, 1997; Stone, 2004). Unlike SH, the incidence of UR was more frequent $(P<0.005)$ in cows $>200$ DIM than in cows $\leq 200$ DIM (Table 2). This could be explained by the theory that the incidence of UR or erosion of the hoof horn in sole and heel surface is primarily due to microbial activity (Nocek, 1997); that is, development of UR needs a longer period of microbial action on damaged hoof areas with inferior horn quality either due to true laminitis or other abrasive environmental factors. First- and second-parity cows had a greater $\Delta \mathrm{T}$ than third- and fourth-parity cows $\left(5.9 \pm 0.7\right.$ vs. $3.5 \pm 0.9^{\circ} \mathrm{C}$, $P=0.05$ ). Horn tissue growth is greater in younger than in mature cows (Vermunt and Greenough, 1995), which results in higher demands for nutrients and blood supply, and, consequently, higher sensitivity to laminitis for the younger cows. The greater frequency of sole ulcers in first-lactation cows compared with older cows reported by Enevoldsen et al. (1991) may also suggest a higher risk of laminitis in younger cows. However, the presence of humans while imaging might disproportionately increase stress and subsequent thermal response in younger cows as compared with older cows.

A greater $\Delta \mathrm{T}(P<0.05)$ was observed for lateral than for medial claws $\left(5.2\right.$ vs. $\left.4.2 \pm 0.6^{\circ} \mathrm{C}\right)$. Greenough and Vermunt (1990) found that the severity of $\mathrm{SH}$ was 3 times greater in lateral compared with medial claws. As $\mathrm{SH}$ are indicators of laminitis and occurred more frequently $(P<0.05$, Table 2$)$ in lateral than in medial claws in the current study, higher temperature of lat-

Table 2. Chi-square frequencies ${ }^{1}$ of laminitic hoof abnormalities in 2 stages of lactation across 2 sampling days $(\mathrm{n}=32$ cows $)$.

\begin{tabular}{|c|c|c|c|c|c|c|c|}
\hline \multirow[b]{3}{*}{ Location } & \multicolumn{2}{|c|}{$\begin{array}{l}\text { Sole hemorrhage } \\
\text { (SH) }\end{array}$} & \multirow{3}{*}{$\begin{array}{l}\text { Underrun heel } \\
\quad \text { (UR) } \\
\text { Hind- } \\
\text { Lateral }\end{array}$} & \multicolumn{2}{|c|}{$\begin{array}{l}\mathrm{SH} \text { in hind claws } \\
\text { by stage of lactation }\end{array}$} & \multirow{2}{*}{\multicolumn{2}{|c|}{$\begin{array}{l}\mathrm{SH} \text { in hind claws } \\
\text { (all cows) }\end{array}$}} \\
\hline & \multirow{2}{*}{$\begin{array}{l}\text { Front- } \\
\text { Lateral }\end{array}$} & \multirow{2}{*}{$\begin{array}{l}\text { Hind- } \\
\text { Lateral }\end{array}$} & & \multirow{2}{*}{$\begin{array}{l}\text { Lateral } \\
\text { claws }\end{array}$} & \multirow{2}{*}{$\begin{array}{l}\text { Medial } \\
\text { claws }\end{array}$} & & \\
\hline & & & & & & Lateral & Medial \\
\hline $\begin{array}{l}\leq 200 \mathrm{DIM}^{3} \\
>200 \mathrm{DIM}^{3}\end{array}$ & $\begin{array}{l}5 \\
1\end{array}$ & $\begin{array}{r}10^{\mathrm{a}} \\
5^{\mathrm{b}}\end{array}$ & $\begin{array}{r}3^{\mathrm{b}} \\
10^{\mathrm{a}}\end{array}$ & $\begin{array}{r}11^{\mathrm{a}} \\
4^{\mathrm{b}}\end{array}$ & $\begin{array}{l}3 \\
2\end{array}$ & $15^{\mathrm{a}}$ & $5^{\mathrm{b}}$ \\
\hline$P<$ & 0.1 & 0.025 & 0.005 & 0.05 & NS & & \\
\hline
\end{tabular}

\begin{tabular}{lcc} 
& \multicolumn{2}{c}{ Claw location $\times$ hoof location } \\
\cline { 2 - 3 } Hoof claw & SH & UR \\
\hline Front lateral & 6 & 6 \\
Front medial & 9 & 12 \\
Hind lateral & 15 & 13 \\
Hind medial & 5 & 7 \\
$P<4$ & 0.005 & 0.005
\end{tabular}

${ }^{\mathrm{a}, \mathrm{b}}$ Frequencies within a category with different superscripts are statistically different $(P \leq 0.05)$; NS = not significantly different $(P>0.05)$.

${ }^{1}$ Frequencies are based on hoof scores $>2$ or the threshold of disturbed claw health for each of SH and UR.

${ }^{2}$ Higher frequency of cases with laminitic SH in lateral vs. medial hind claws across 2 stages of lactation.

${ }^{3}$ Early/midlactation $=\leq 200 \mathrm{DIM}, \mathrm{n}=17$; late lactation $=>200 \mathrm{DIM}, \mathrm{n}=15$.

${ }^{4}$ Effect of "claw location $\times$ hoof location" on frequencies of SH and UR. 
eral claws compared with medial claws was expected. van Amstel et al. (2004) reported that lateral claws were thinner than medial claws. Due to unequal distribution of body weight between claws of hind legs (van Amstel et al., 2004), lateral claws may have carried more weight than medial claws, which in turn may have led to disproportionate and faster wear of the lateral claws in the current study. The faster growth of lateral than of medial digits was also discussed by Nocek (1997). It thus can be postulated that the corium and subcutaneous tissues of lateral claws may have a higher turnover rate of cells compared with medial claws, which requires an increased supply of blood and nutrients.

Lateral claws in hind hooves and medial claws in front hooves were more affected by $\mathrm{SH}$ and UR than were other claws (Table 2). This agrees with the findings of Donovan et al. (2004), who reported similar results for scores of $\mathrm{SH}$ in front and hind hooves.

Temperatures of the coronary band and $\Delta \mathrm{T}$ were higher in early/midlactation cows compared with late lactation cows. Thus, it is possible that skin temperature measurement using IRT could detect inflammation associated with laminitis in early/midlactation. The incidence of $\mathrm{SH}$, which is an indicator of laminitis, was also greater among cows $\leq 200$ DIM compared with cows in later lactation. Therefore, IRT may have potential as a detection tool for laminitis. However, more data on the relationship between IRT and hoof abnormalities, preferably in longitudinal studies, and further quantification of nonlaminitis factors affecting hoof temperature are required before IRT could be recommended for dairy industrial use.

\section{ACKNOWLEDGMENTS}

Authors would like to express their gratitude to A. L. Schaefer of Agriculture and Agri-Food Canada for the loan of the infrared camera. The staff at the Glenlea Research Station, as well as T. Garner, D. Fulawka, and G. Gozho is thanked for technical assistance, and G. Crow and L. Onischuk are thanked for their advice on the statistical analyses. Financial support (to JCP) of the National Sciences and Engineering Council of Canada (NSERC) is gratefully acknowledged.

\section{REFERENCES}

Bergsten, C. 1993. A photometric method for recording hoof diseases in cattle, with special reference to hemorrhages of the sole. Acta Vet. Scand. 34:281-286.

Berry, R. J. 1999. A systems study of lameness in dairy cattle: Effects of behavior and production. Ph.D. Diss. University of Edinburgh, UK.

Berry, R. J., A. D. Kennedy, S. L. Scott, B. L. Kyle, and A. L. Schaefer. 2003. Daily variation in the udder surface temperature of dairy cows measured by infrared thermography: Potential for mastitis detection. Can. J. Anim. Sci. 83:687-693.

Canadian Council on Animal Care. 1993. Guide to the Care and Use of Experimental Animals. Vol. 1. E. D. Olfert, B. M. Cross, and A. A. McWilliam, ed. CCAC, Ottawa, ON, Canada.

Donovan, G. A., C. A. Risco, G. M. DeChant-Temple, T. Q. Tran, and H. H. van Horn. 2004. Influence of transition diets on occurrence of subclinical laminitis in Holstein dairy cows. J. Dairy Sci. 87:73-84.

Eddy, A. L., L. M. van Hoogmoed, and J. R. Snyder. 2001. Review: The role of thermography in the management of equine lameness. Vet. J. 162:172-181.

Enevoldsen, C., Y. T. Gröhn, and I. Thysen. 1991. Sole ulcers in dairy cattle: Associations with season, cow characteristics, disease, and production. J. Dairy Sci. 74:1284-1298.

Green, L. E., V. J. Hedges, Y. H. Schukken, R. W. Blowey, and A. J. Packington. 2002. The impact of clinical lameness on the milk yield of dairy cows. J. Dairy Sci. 85:2250-2256.

Greenough, P. R., F. J. MacCallum, and A. D. Weaver. 1981. Lameness in cattle. Pages 124-150 (Chapter 8) in Anatomy of the Digital Region. 2nd ed. A. D. Weaver, ed. Lippincott Co., Philadelphia, PA.

Greenough, P. R., and J. J. Vermunt. 1990. Evaluation of subclinical laminitis and associated lesions in dairy cattle. Update in cattle lameness. Pages 45-54 in Proc. VIth Int. Symp. Dis. Ruminant Digit, Liverpool, UK. Br. Cattle Vet. Assoc., Frampton-on-Severn, UK.

Nocek, J. E. 1997. Bovine acidosis: Implications on laminitis. J. Dairy Sci. 80:1005-1028

Schaefer, A. L., N. Cook, S. V. Tessaro, D. Deregt, G. Desroches, P. L. Dubeski, A. K. W. Tong, and D. L. Godson. 2004. Early detection and prediction of infection using infrared thermography. Can. J. Anim. Sci. 84:73-80.

Schwartzkopf-Genswein, K. S., and J. M. Stookey. 1997. The use of infrared thermography to assess inflammation associated with hot-iron and freeze branding in cattle. Can. J. Anim. Sci. 77:577-583.

Stone, W. C. 2004. Nutritional approaches to minimize subacute ruminal acidosis and laminitis in dairy cattle. J. Dairy Sci. 87(E. Suppl.):E13-E26.

van Amstel, S. R., J. K. Shearer, and F. L. Palin. 2004. Moisture content, thickness, and lesions of sole horn associated with thin soles in dairy cattle. J. Dairy Sci. 87:757-763.

Vermunt, J. J., and P. R. Greenough. 1995. Structural characteristics of the bovine claw: Horn growth and wear, horn hardness and claw conformation. Br. Vet. J. 151:157-180. 